Journal of the Scholarship of Teaching and Learning, Vol. 21, No. 4, December 2021, pp. 100-110. doi: 10.14434/josotl.v21i4.32845

\title{
Debate for Civic Learning: A Model for Renewing Higher Education's Civic Mission
}

\author{
Paul E. Mabrey III ${ }^{1}$, Kevin E. Boston-Hill ${ }^{2}$, Drew Stelljes ${ }^{3}$, and Jess Boersma ${ }^{4}$ \\ ${ }^{1}$ James Madison University \\ ${ }^{2}$ Hofstra University \\ ${ }^{3}$ William \& Mary \\ ${ }^{4}$ University of North Carolina Wilmington
}

\begin{abstract}
Rapidly eroding financial support and tuition increases that outpace inflation threaten the viability of an education that considers civic engagement as foundational. Simultaneously, institutions of higher education are increasingly perceived by the public as market-driven entities existing for the economic benefit of the individual, the upward mobility of a social class, and in turn the further sedimentation of racial and class differences. Now, more than ever, our nation is in need of deliberate attempts to fashion common understandings, ways to navigate inevitable disagreements, and reasonable paths forward. Higher education is positioned to respond to these civic needs but requires a commitment to be bold and remain dedicated to our shared civic mission in the face of alarming polarization and vacated institutional trust. One way institutions of higher education can return to their shared sense of civic mission is with the integration of debate across the curriculum through innovative partnerships and collaborative design. Debate across the curriculum utilizes intentional course redesign to offer active learning experiences that combine public speaking, evidence-based reasoning, collaborative learning, and argumentation into various advocacy simulations. The debate for civic learning model bas faculty partnered across multiple institutions to design, integrate, and assess debate-based pedagogy to positively impact student civic learning. Students and faculty across disciplines have reported that debate-based pedagogy helped improve classroom engagement, critical problem solving, perspective taking, empathy, and advocacy skills. This mixed-method research provides insights not only into debate-based course design and learning improvement strategies but also into how faculty, students, and administrators can partner between institutions to demonstrate a shared commitment to the civic mission of higher education and democratic promise of our nation.
\end{abstract}

Keywords: civic learning, debate pedagogy, faculty development, advocacy, interinstitutional collaboration.

The prospects for attaining a civically orientated education have become increasingly threatened by the rapidly eroding financial support for public higher education, tuition increases that outpace inflation, and societal polarization that has transcended its place within electoral politics into everyday public discourse, health communication, local $\mathrm{K}-12$ educational decision making, and postsecondary education. Integrating civic engagement into American higher education is further complicated by long-running but recently supercharged concerns such as indoctrination into a given politics, free speech (and what that might even mean), and individual accountability over pedagogical, programmatic, and/or institutional decisions. Now more than ever, colleges and universities should take the hard road, the path that has meaning and purpose, where engagement means fixing the system that created our national conundrum (National Task Force on Civic Learning and Democratic Engagement, 2012).

As educators, we must be bold in the face of eroded or vacant trust in the civic mission of the American public university and remain wholly dedicated to our shared civic mission (Hoffman et al., 
2018; Levine, 2006). Colleges devoted to their civic mission educate for the citizenry and for citizenship. A civic engagement framework focused on teaching and assessing the knowledge, skills, and attitudes necessary for participating in community living will allow our society to persist, to exist through this turmoil of the first part of the century (Beaumont, 2005). The public needs colleges and universities to train for the constructive exchange of ideas and the peaceful cooperation among a diverse citizenry with myriad perspectives on hard-to-solve problems (Gormley, 2017; Westheimer \& Kahne, 2004).

In the pages that follow, we provide an overview of the origins and implementation of the Colonial Academic Alliance (CAA) Debate for Civic Learning initiative. We then outline and reflect on two specific classroom exercises involving debate pedagogy that were conducted by two of the authors to provide a more detailed description of the challenges and opportunities. Zooming out, we analyze the aggregated results of all 11 classes across six institutions in the areas of student participants' civic learning dispositions and civic learning skills. As this initiative has just completed its 1st year of a 2-year timeline, the reflections will be targeted at the opportunities for increasing, improving, and sustaining the reach of debate for civic learning.

\section{The CAA Innovate/Collaborate Grant Program and the Debate Pedagogy Plan}

The CAA Debate for Civic Learning initiative is modeled after a pilot program developed by James Madison University (JMU), Virginia Commonwealth University (VCU), and the State Council of Higher Education for Virginia. The pilot program supported 12 faculty at JMU and VCU to implement and assess debate for civic learning in their respective classes, impacting hundreds of students. Here, civic learning focused on the skills and dispositions that aligned with both civic engagement and debate-based pedagogy (Bellon, 2005; Lundberg, 2010; Mitchell, 2000; Tonkins, 2019; Torney-Purta et al., 2015; Winkler, 2010). Preliminary data from students who participated in these courses indicate that the use of debate-based pedagogy positively impacted student learning across a number of learning objectives (critical thinking, communication, collaboration) and, in particular, civic learning. Of particular interest were attitudes about engaging in public advocacy and political awareness and self-reported assessments of civically relevant skills such as research, public speaking, critical thinking, problem solving, and empathy. These results confirm prior framings of the pedagogical benefits of debate or other argument-based assignments for improving student civic learning (Hogan et al., 2016; Rowland, 2017). Data from the pilot show students across different disciplines reported an increase in their ability to listen to a variety of perspectives on political issues, compared to a reported decrease in a control group. Moreover, $79 \%$ of participants in the debate for civic learning intervention rated their ability to consider others' perspectives a little or much better compared to before the curricular intervention, and $70 \%$ rated their ability to have a civil disagreement a little or much better than before the intervention.

The pilot program also featured a 2-day institute that had 70 faculty, staff, and students from around the Commonwealth learning about the use of debate-based pedagogy for civic learning. This collaborative model for faculty development also served as an opportunity for faculty, staff, and students from the pilot faculty cohort to showcase work they had done in using debate as a highimpact practice to positively impact student civic learning. Following the initial success of the pilot program, JMU proposed expanding the scope of the program to other member institutions of the Colonial Athletic Association through its emerging academic wing: the CAA. Through a competitive innovate/collaborate (IN/CO) grant process, the CAA Debate for Civic Learning initiative is a funded, 2-year program designed to build on the evidence-based practices of the pilot cohort.

As a result, JMU collaborated with six other CAA institutions (College of Charleston, Hofstra, Northeastern, Towson, University of North Carolina Wilmington, William \& Mary) to develop their

Journal of the Scholarship of Teaching and Learning, Vol. 21, No. 4, December 2021. josotl.indiana.edu 
own capacity to support integrating debate-based pedagogy for positively impacting student civic learning in fall 2020, which led to the delivery of 11 new courses in spring 2021. Faculty from the first cohort in 2020-2021 spanned several disciplines: English, political science, global studies and geography, rhetoric, engineering, communication studies, dance, and public policy. The cohort participated in workshops over the fall semester focused on course design, debate-based pedagogy, and assessment. Only two case studies follow, in public policy and rhetoric, respectively, but additional information on other classes is accessible in the CAA Debate for Civic Learning open educational resource (Baker et al., 2021).

\section{Case 1: Leadership Education and Democratic Engagement}

In the spring 2021 semester, a coauthor developed a discussion-intensive course that examined the relationship between leadership education and democratic engagement in modern American life. Students examined whether leadership education contributes to a just, equitable, and democratic society. Through various discussion and deliberation techniques, students dissected leadership theory in practice. They examined the way speeches and videos presented topics of political or social concern and how they portrayed individuals and groups in the dilemma. Through discussion and case studies, they debated whether leadership education advances dominant narratives that are harmful and disempowering to underrepresented subpopulations.

Using various historical texts from the humanities along with contemporary critical theory of leadership, students mapped historical narrative and contemporary dominant leadership paradigms with leadership in public policy and citizen engagement. In class, the students experimented with synthesizing material from seemingly unrelated texts and time periods to develop sophisticated analyses of contemporary relationships between leadership education and democratic engagement in American life. Discourse, discussion, informed debate, and disagreement with civility were the expectations in this seminar.

The class utilized the online OpenMind platform (https://openmindplatform.org), an evidence-based approach to constructive dialogue developed by Jonathan Haidt and Caroline Mehl. The platform, consisting of eight modules, equips students with the knowledge and skills to communicate constructively about topics that evoke intense emotions. These modules emerged as a central part of the content and became tools to facilitate discussion. OpenMind explores the inner workings of the mind and the psychological roots of human differences. The online program consists of eight lessons and optional peer-to-peer guided conversations that match the lessons. The lessons provide users with practical, evidence-based skills to communicate constructively across differences. Lessons take participants from an exploration of the working of the mind and the challenges of rational thinking to practical methods for practicing rational thought throughout a disagreement. Students learned how people's histories and their interpretation of life experiences shape their worldview and values. The coauthor introduced students to the platform and explained the significance of the lessons to the course goals. The professor integrated the skills into the weekly discussions. Students were paired with a classmate for semistructured discussions based on the lessons every 2 weeks over an 8 -week period.

In class, students practiced using the tools presented on the platform. For example, students viewed a video clip from a major news channel. In the video, residents of a small town in the Midwest of the United States were asked to explain the reasons for their support for former President Donald Trump. Students examined the various responses from both the residents and the reporter and reflected on how the responses led to further misunderstandings and dissatisfaction. Students then developed a revised script for the interview based on the skills discussed in the lessons. In addition, several guest speakers presented real cases from their work for the students to consider using

Journal of the Scholarship of Teaching and Learning, Vol. 21, No. 4, December 2021. josotl.indiana.edu 
discussion and listening techniques. John Bridgeland, CEO of Civic, presented a scenario on how to create a culture of collaboration across stakeholder groups. The Chief of Staff for a U.S. Senator walked students through an exercise on responding to the attack on the U.S. Capitol on January 6, 2021. The staffer explained the emotions felt during the insurrection and the subsequent responses in the days after the attack.

Uncovering the roots of human differences was examined in practice through paired and small group discussions of the impact members of one's family have on shaping one's perceptions of education, religion, and political and social concerns. Students completed a values inventory and explored how taking a values-centered approach to discussions can be both productive and potentially harmful depending on the strategy. Students studied the practice of cultivating intellectual humility and curiosity in learning and understanding diverse perspectives through the technique of fishbowl discussions. For such discussions, most students sit in an inner circle (the fishbowl) while the rest of the students sit in a larger, outer circle. The students in the inner circle discuss the topic while the other students listen intently to the conversation. Devoting time to listening allowed students to practice strategies for understanding other people better and find common ground through a gradual process of expression and understanding.

\section{Case 2: Logical Reasoning and Argument: A Lesson in Civil Discourse}

During an oral communications class where students examined the different speaking styles of the presidential candidates, the conversation drifted to a discussion about how to express a particular point without waging a personal attack on your opponent. As the discussion continued, it became evident that the students did not have any formal training in the art of civil discourse; while they presented their opinions with passion and fervor, there was no evidence to back up or refute claims. Rather, the arguments were filled with hypotheticals and conjecture that quickly broke down to a lot of talking over each other without listening. Once order was restored, many students revealed they had never had any formal training in argumentation and would welcome such an opportunity. Thus, one coauthor developed a section on logical reasoning and argument.

Although this idea was originally born out of a conversation with students in the oral communications class, the coauthor decided to extend the idea to the students of another public speaking class as well. This way the co-author, as instructor, could compare student development in discourse from both an individual stance (public speaking course) and a group position (oral communication course). The co-author broke this section into several component lessons: critical listening, persuasive concepts, and logical reasoning.

\section{Component Lessons}

Critical listening. In this lesson, students reviewed the familiar term active listening and then examined the different types of listening-engaged, relational, and critical-as well as when each type is employed. They then explored the obstacles to listening to gain an understanding of why messages "get lost in translation" as well as how to recognize these obstacles and mitigate their impact. Students were then led through an exercise to practice their listening skills and were instructed to note, outside of class, the number of times they recognized and allowed various obstacles to interfere with their listening and analysis of messages - whether those messages were during class or casual conversation with friends and family.

Persuasive concepts. To understand that the ability to persuade others (the crux of any argument or debate) is an important skill, students were introduced to the rhetorical concepts of ethos (appeal to authority), logos (appeal to logic), and pathos (appeal to emotion). The class first examined these

Journal of the Scholarship of Teaching and Learning, Vol. 21, No. 4, December 2021. josotl.indiana.edu 
concepts through commercials and print advertisements to see how companies use them to persuade consumers. The class then conducted a close reading of Dr. Martin Luther King, Jr.'s "I Have a Dream" speech as an example of how these persuasive concepts are used in tandem to convince the masses to join and further the Civil Rights Movement. As further practice and demonstration of an understanding of the concepts, students had to create their own commercials related to a product to sell, group to join, or idea to further. Their classmates judged the amount of persuasiveness of each presentation.

Logical reasoning. After students learned about the various persuasive concepts, it became necessary to focus their attention on how to use them in regular conversation and discourse. The instructor asked the students to take a stance on a prompt — strongly agree, agree, disagree, strongly disagree-and provide a reason for taking that stance. As anticipated, most students found no problem with taking a definitive stance. Where the difficulty came was providing the reason. The reasons were little more than opinions and how they felt about the prompt. The reasoning lacked evidence to make it convincing. The class explored the different forms of reasoning (inductive, deductive, analogy) as well as the elements of an argument (claim; grounds/evidence; warrant, i.e., the link between grounds and claim; backing, i.e., additional support to explain the warrant; and qualifiers, i.e. statements that limit how universally the warrant applies). The elements were simplified to the acronym ARE: assertion (the simple statement or claim), reasoning (the "because" part of the argument), and evidence (the examples and proof cited). The class read examples of everyday arguments they might have seen in the form of letters to the editor and examined them against ARE for completeness. Students were then tasked to create their own letter to the editor on a topic of their choosing to demonstrate understanding of how to create and present an effective argument.

\section{The Debate/Panel Discussion}

The above sequence was taught to both the oral communications class and the public speaking class. While the information each class received was the same, the culminating project was not. The public speaking class, since it lent itself to more individualism, was tasked with staging a debate. Students in this class were thus also taught the additional element of rebuttal - a response to counterarguments. They were assigned in groups of four (two people would argue on each side of the topic). They also had to focus on different points of the argument to avoid any repetition. The groups could choose what format they would use for their debate-AABB, ABAB, or ABBA — and their classmates would judge which side had the more convincing argument. They were graded on the basis of how explicit their claim was, how they set it up (relevance), how evidence was connected to their claim, and how much they actually listened to the opposition when fashioning their rebuttal.

The oral communications class had more of an emphasis on the group dynamic and thus its students were tasked with creating panel discussions on a topic of their choosing. Students were placed in groups of five (a moderator and four panelists, though the moderators could inject themselves into the conversation as well). Each panelist had to pick a different angle from which to address the topic to demonstrate their "expertise." Students were graded on the basis of how explicitly the problem was stated, how much evidence was cited when the arguments were given, and how much panelists listened and responded to each other as well as to the questions from the moderator.

In both classes students had not only to demonstrate the ability to listen critically but also to practice restraint in waiting for their classmates to finish their thoughts before expressing their own opinion. Even then, students had to preface their statement with a rebuttal technique taught to keep the argument focused on the issue at hand and to take some of the emotion out of the response.

Journal of the Scholarship of Teaching and Learning, Vol. 21, No. 4, December 2021. josotl.indiana.edu 


\section{Analysis}

As mentioned earlier, the CAA IN/CO grant has supported the growth of this model for integrating debate-based pedagogy to enhance civic learning. Originally a model developed for debate across the curriculum within JMU and then in a collaborative partnership with VCU (Fisler \& Pelco, 2020), the CAA Debate for Civic Learning project has incubated it to grow between and take hold within seven different institutions. The model entails subject-matter experts in debate-based pedagogy leading a course design process with a cohort of faculty in the fall semester and then supporting the implementation and assessment of the courses during the subsequent spring semester. As the two case studies suggest, debate for civic learning may look like more traditional debate formats, deliberative panels, fishbowl discussions, or other role-playing and scenario-based learning activities that integrate reasoned advocacy, evidence-based decision making, perspective-taking, and communicating clearly with intended audiences.

\section{Quantitative Results}

During the spring 2021 semester, nine faculty offered 11 classes across six institutions that integrated some form of debate-based curriculum orientated toward civic learning objectives. For some faculty, this was an isolated unit or module that featured a traditional debate assignment; others integrated an advocacy role-play scenario that had students arguing and advocating from particular perspectives around a given controversy or social issue.

All faculty shared the research survey (Institutional Review Board approved) in the first 2 and the last 2 weeks of the academic semester. The two scales reported here were adapted from the Political Engagement Project survey (PEPS), labeled civic learning dispositions and civic learning skills, respectively (James Madison Center for Civic Engagement, n.d.). Items were adapted from the PEPS based on their fit with the learning outcomes and instructional activities of the CAA model. For example, not all items related to civic abilities or attitudes were emphasized or considered as an outcome. Subsequently, results are reported by item rather than as subscales. Furthermore, the themes from two open-ended questions (relevance for future work and what students liked least), are also reported.

From the 11 classes offered, 184 students completed the presurvey, 115 completed the postsurvey, and 78 completed both. The undergraduate participants reported being mostly White $(\sim 80 \%)$, female $(\sim 60 \%)$, evenly split between 1 st-year/sophomore and upper-class undergraduates $(\sim 45 / 55 \%)$, and generally with no $(\sim 44 \%)$ or merely high school $(\sim 50 \%)$ class debate experience.

Students who participated in debate-based pedagogy reported an increase in their civic learning dispositions. Dependent-samples $t$ tests were run for each of the five items on the Civic Disposition scale and each item demonstrated a statistically significant increase with a large effect size after students participated in the debate-based curriculum in their specific course (see Table 1). For example, on the disposition that students saw themselves as well qualified to participate in the political process, they went from somewhat disagree $(M=3.99, S D=1.42)$ to right in between agree and strongly agree $(M=4.47, S D=1.44)$.

Journal of the Scholarship of Teaching and Learning, Vol. 21, No. 4, December 2021. josotl.indiana.edu 
Table 1. Results of Debate Pedagogy Participants' Civic Dispositions Dependent-Samples $t$ Tests $(N=78)$.

\begin{tabular}{|c|c|c|c|c|c|c|c|}
\hline \multirow[t]{2}{*}{ Scale item } & \multirow[t]{2}{*}{$M$} & \multirow[t]{2}{*}{$S D$} & \multirow[t]{2}{*}{$t(77)$} & \multirow[t]{2}{*}{$p$} & \multirow[t]{2}{*}{ Cohen's $d$} & \multicolumn{2}{|c|}{ Postsurvey } \\
\hline & & & & & & $M$ & $S D$ \\
\hline $\begin{array}{l}\text { I feel I have a pretty good understanding of } \\
\text { the political issues facing our country. }\end{array}$ & 4.64 & 0.99 & -2.026 & .046 & 0.84 & 4.83 & 0.97 \\
\hline $\begin{array}{l}\text { I believe that I have a role to play in the } \\
\text { political process. }\end{array}$ & 4.55 & 1.28 & -2.132 & .036 & 1.06 & 4.81 & 1.23 \\
\hline $\begin{array}{l}\text { When policy issues or problems are } \\
\text { discussed, I usually have something to say. }\end{array}$ & 4.35 & 1.27 & -3.366 & $<.001$ & 0.96 & 4.74 & 1.25 \\
\hline $\begin{array}{l}\text { I think I am better informed about politics } \\
\text { and government than most people. }\end{array}$ & 3.88 & 1.40 & -4.083 & $<.001$ & 1.05 & 4.37 & 1.43 \\
\hline $\begin{array}{l}\text { I consider myself well qualified to } \\
\text { participate in the political process. }\end{array}$ & 3.99 & 1.42 & -3.748 & $<.001$ & 1.15 & 4.47 & 1.44 \\
\hline
\end{tabular}


Student participants also reported increases in the skills necessary for participation in civic life (see Table 2). While means comparison was not appropriate on these items because of the inclusion of an "I don't know if I can do this" response, students generally reported an increase, with an especially noticeable increase on civic learning skills that involve communication, critical thinking, and advocacy. For example, students' agreement on their ability to write or speak in appropriate civic forums or take a position and defend it increased nearly $20 \%$ on average at the end of the semester compared to at the very beginning of the same semester. Also of note is the nearly $15 \%$ increase on average in critical civic skills such as problem-solution evaluation and use of critical inquiry for public decision making.

Table 2. Percentage of Students Who Reported They Could Perform Civic Learning Skills.

\begin{tabular}{lcc}
\hline Civic learning skill & $\begin{array}{c}\text { Presurvey }(\%) \\
(N=184)\end{array}$ & $\begin{array}{c}\text { Postsurvey (\%) } \\
(N=115)\end{array}$ \\
\hline $\begin{array}{l}\text { Listen to a variety of perspectives on political issues } \\
\begin{array}{l}\text { Write effectively and persuasively in forums appropriate to } \\
\text { civic life and public affairs }\end{array}\end{array}$ & 57 & 85 \\
$\begin{array}{l}\text { Speak effectively and persuasively in forums appropriate to } \\
\text { civic life and public affairs }\end{array}$ & 58 & 79 \\
$\begin{array}{l}\text { Explain diverse positions on democratic values and } \\
\text { practices; take a position and defend it }\end{array}$ & 61 \\
$\begin{array}{l}\text { Take a position on democratic values and practices and } \\
\text { defend it }\end{array}$ & 70 \\
$\begin{array}{l}\text { Distinguish reliable and valid evidence and facts from } \\
\text { unsubstantiated claims }\end{array}$ & 73 \\
$\begin{array}{l}\text { Recognize the impact all forms of media have on personal } \\
\text { attitudes and political beliefs }\end{array}$ & 88 & 83 \\
$\begin{array}{l}\text { Evaluate strengths and weaknesses of potential approaches } \\
\text { to civic and political problems }\end{array}$ & 75 & 89 \\
$\begin{array}{l}\text { Use critical inquiry, analysis, and reasoning to identify a } \\
\text { contemporary problem, research solutions, analyze results, } \\
\text { evaluate choices, and make decisions }\end{array}$ & 72 & 90 \\
$\begin{array}{l}\text { Effectively work across differences to reach collaborative } \\
\text { decisions that best support democracy and civic life }\end{array}$ & 80 & 90 \\
\hline
\end{tabular}

\section{Emerging Themes}

The benefits of debate-based pedagogy extend beyond the increase in student-reported civic learning dispositions and skills to areas of future work. Eleven themes were identified in the participantgenerated answers to the question of what part, if any, of the debate or argumentation activity might be relevant to their future work, including the following:

- ability to organize arguments and debate

- ability to research, identify, and understand diverse perspectives

- ability to listen

- collaboration

- identifying the value of or one's attitude toward argument, research, or civic discourse

Journal of the Scholarship of Teaching and Learning, Vol. 21, No. 4, December 2021. josotl.indiana.edu 
- critical thinking; responding to others' arguments

- advocating for something one believes in

- general public speaking

The responses provided a depth and richness to the quantitative improvements in civic learning. For example, one participant mentioned, "I will definitely look at different people's perspectives differently - especially when it comes to paradigms and how different people look at the same problem through different paradigms. Ultimately, I can better understand and think critically about different perspectives." This participant demonstrated a meta-awareness of how fundamental belief systems can shape people's perspectives and an improved ability to critically understand and engage them. Another participant said, "it showed me to really listen to someone's opinion and their thoughts on a situation and how to respond to it. To not jump to conclusions and not listen to what they have to say." More than listening and empathy, the debate-based pedagogy emphasized a critical reflection necessary for civic engagement. As one student said, "I think mindfullness [sic] of people's underlying values and of your own automatic processing (especially how to consciously challenge those thoughts) were really valuable skills to gain. Thinking about these things made me a more active and purposeful listener."

Twelve themes emerged about what students said they liked least about the debate- or advocacy-related intervention in their class through an open-ended question. Issues highlighted by participants included:

- the process for topic/side/role selection

- anxiety about public speaking generally and debates especially

- online format had students not taking the assignment seriously or asymmetrical expectations in hybrid flexible modality

- not enough time or space committed to activity in the course

- students were positioned to argue a perspective they disagreed with

- difficulty thinking and responding in the moment

- too little cross-examination

- problems with group collaboration (e.g., too little or that their groups were bad)

- choices students made for their presentations (e.g., talked too fast, presented little evidence)

- more instruction on structure and assignment expectations

- others' views (e.g., made them uncomfortable, people got upset, too close minded)

- little or no role for students in the audience

For example, one participant shared that "the issue with doing some of these activities is that there are unpredictable moves from classmates which can be upsetting at times." Another participant explained, "I wish more people came to listen instead of just be right and there being no way they're wrong." Rather than serve as roadblocks or reasons to abandon debate-based pedagogy, this feedback can inform curricular revisions and innovation and the development of additional resources for students and faculty as well as moments of intentional class reflection and discussion.

\section{Reflection on the Implications and Possible Generalization to Other Settings or Populations}

The model shared here represents one path toward renewing higher education's civic mission, and it does so taking into account different perspectives of higher education governance, whether from a classroom, programmatic, or even inter-institutional perspective. From the classroom perspective, integrating debate-based pedagogy represents an active form of learning that both engages faculty and 
curates learning experiences for students that teach and reinforce essential civic learning skills (TorneyPurta et al., 2015). Although many might hesitate at the use of debates for teaching civic learning skills such as listening, perspective taking, and empathy, the curricular cases shared here and the results demonstrate that debate-based pedagogy is much more than just yes/no advocacy exercises. For example, the data collected here support the role that listening and empathy can and should play in better understanding, teaching, and assessing civic learning (Dobson, 2012). The faculty here redesigned existing courses to integrate scaffolded debate, argument, and advocacy exercises that modeled for students what civic engagement is capable of engendering. Instead of approaching controversies as one dimensional and merely opinion based, the CAA Debate for Civic Learning model helped faculty across disciplines and institutions design learning outcomes, curricula, and assessments that involved cooperative and social learning, risk taking, public controversies, evidencebased reasoning, perspective taking, public communication, and reflection.

Within an institution and at a departmental, programmatic, or even institutional level-the CAA Debate for Civic Learning model can provide a touchstone for how students, staff, and faculty can connect around civic learning. Within a program or department, debate-based pedagogy can be used to help meet or design new student learning outcomes. Debate-based pedagogy has been used to help faculty and students positively impact student learning on oral communication or critical thinking, for example, in addition to civic learning (Bellon, 2000; Hogan et al., 2016). For example, at one coauthor's institution this pedagogy is being piloted as a key component of a new, university-wide oral competency requirement in development. Moreover, the collaborative model used here produced some of the first empirical evidence demonstrating the positive impacts that debate-based pedagogy can have on civic learning, especially interesting given its use across disciplines and institutions.

Between institutions, the model supported here through the CAA IN/CO grant shows how both champions of and novices to civic learning across institutions can gather to gain sustaining momentum for higher education's civic mission. Ongoing analyses are examining faculty participants' perspective on this work, which will provide a valuable feedback loop as the CAA IN/CO grant builds faculty and institutional capacity through a peer-learning community, a dedicated website and a Civic Learning Institute hosted by JMU and open to all participating institutions in the CAA.

\section{Acknowledgments}

The authors would like to thank the CAA Provost's Council for its financial support through the IN/CO program, as well as Lindsey Interlante, CAA executive director, for facilitating interinstitutional collaborations. We would also like to thank all the faculty members and institutional leads who are participating in this ongoing work to create brave spaces for civic learning and engagement.

\section{References}

Baker, J., Bollinger, D., Boston-Hill, K. E., Gipson, K., Harris, A., Stockwell, S., Warnick, C., \& Wofford, C. (2021). Course materials to support the Colonial Academic Alliance's Debate for Civic Learning, James Madison University: Harrisonburg, $V A$. https://www.jmu.edu/commcenter/facstaff/debate-across-the-curriculum/CAA 2021 OER.pdf

Beaumont, E. (2005). The challenge of assessing civic engagement: What we know and what we still need to learn about civic education in college. Journal of Public Affairs Education, 11(4), 287303. https://doi.org/10.1080/15236803.2005.12001403

Bellon, J. (2000). A research-based justification for debate across the curriculum. Argumentation and Advocacy, 36, 161-175. https://doi.org/10.1080/00028533.2000.11951646

Journal of the Scholarship of Teaching and Learning, Vol. 21, No. 4, December 2021. josotl.indiana.edu 
Dobson, A. (2012). Listening: The new democratic deficit. Political Studies, 60(4), 843-859. https://doi.org/10.1111/j.1467-9248.2012.00944.x

Fisler, J., \& Pelco, L. E. (2020). Civic engagement in Virginia's public higher education institutions. Diversity \& Democracy, 22(4). https://www.aacu.org/diversitydemocracy/2020/summer/fisler

Gormley, W. T., Jr. (2017). The critical advantage: Developing critical thinking skills in school. Harvard Education Press.

Hoffman, D., Domagal-Goldman, J., King, S., \& Robinson, V. (2018). Higher education's role in enacting a thriving democracy: Civic learning and democratic engagement theory of change. http://apps.naspa.org/files/CLDE-Theory-of-Change.pdf

Hogan, J. M., Kurr, J. A., Johnson, J. D., \& Bergmaier, M. J. (2016). Speech and debate as civic education. Communication Education, 65(4), 377-381. https://doi.org/10.1080/03634523.2016.1203002

James Madison Center for Civic Engagement. (n.d.). Civic engagement \& political learning assessment. https://www.jmu.edu/civic/assessment.shtml

Levine, P. (2006). Learning and democracy: Civic education. The Kettering Review, 24(3), 32-42.

Lundberg, C. O. (2010). The Allred Initiative and debate across the curriculum: Reinventing the tradition of debate at North Carolina. In A. D. Louden (Ed.), Navigating opportunity: Policy debate in the $21^{\text {st }}$ century (pp. 289-321). Idebate Press.

Mitchell, G. R. (2000). Simulated public argument as a pedagogical play on worlds. Argumentation and Advocacy, 36(3), 134-150. https://doi.org/10.1080/00028533.2000.11951644

National Task Force on Civic Learning and Democratic Engagement. (2012). A crucible moment: College learning and democracy's future. Association of American Colleges and Universities.

Rowland, R. C. (2017). Public debate and American democracy: Guidelines for pedagogy. In J. M. Hogan, J. A. Kurr, M. J. Bergmaier, \& J. D. Johnson (Eds.), Speech and debate as civic education (pp. 81-93). The Pennsylvania State University Press.

Tonkins, M. (2019). Debate across the curriculum: A case study. Communication Center Journal, 5(1), 187-188.

Torney-Purta, J., Cabrera, J. C., Roohr, K. C., Liu, O. L., \& Rios, J. A. (2015). Assessing civic competency and engagement in higher education: Research background, frameworks, and directions for next-generation assessment. ETS Research Report Series, 2015(2), 1-48. https://doi.org/10.1002/ets2.12081

Westheimer, J., \& Kahne, J. (2004). What kind of citizen? The politics of educating for democracy. American Educational Research Journal, 41, 237-269. https://doi.org/10.3102/00028312041002237

Winkler, C. (2011). To argue or to fight: Improving at-risk students' school conduct through urban debate. Controversia, 7(2), 76-90. 